\title{
Sir William Crookes (1832-1919) Biography with special reference to X-rays
}

\author{
Richard F. Mould
}

Sir William Crookes was one of the most famous scientists towards the end of the $19^{\text {th }}$ and in the early $20^{\text {th }}$ centuries and even today, his face with its waxed moustache is easily recognisable among scientists, (Fig. 1). His name is forever associated with the Crookes tube, a gas discharge tube used for the production of X-rays. He is also famous for being one of the few men who had actually produced X-rays in an experimental environment, but who never recognised them as such. He could have preceded Röntgen in the discovery of X-rays by some 15 years! He was a physicist, chemist and inventor, discovering the metal thallium in 1861 and devising the radiometer as a measuring device, and the spinthariscope. He used radium to study the artificial changes in colour of diamonds. Towards the latter part of his life he became interested in spiritualism and in some circles lost a certain amount of credibility because of this interest. He received many honours, including the 1907 Nobel Prize for Chemistry, President of the Royal Society and a knighthood.

NOWOTWORY J Oncol 2017; 67, 1: 79-88

Key words: Sir William Crookes, Crookes family genealogy, thallium, X-rays, Crookes tubes, Maltese cross X-ray tube, mercury air pumps, radiometer, Hermann Sprengel, Johann Geissler, Julius Plücker, Johann Hittorf, Michael Faraday, Antoine-Henri Becquerel, discovery of radioactivity, spinthariscope, radium, diamonds, spiritualism

\section{Introduction}

Born in London, William Crookes was a pupil and assistant of August Hoffmann at the Royal College of Chemistry. He was then superintendent of the meteorological department at the Radcliffe Observatory, Oxford and from 1855 lectured on chemistry at the Science College, Chester. He discovered the metal, thallium, in 1861 and the sodium amalgamation process in 1865 . He also improved vacuum tubes (Fig. 2), promoted electric lighting, invented the radiometer 1873-1876, and the spinthariscope. He was the author in 1871 of the book Select Methods of Chemical Analysis [1]. He is known to have produced X-rays before Röntgen's discovery, but not to have recognised them for what there were. He experimented with diamonds in terms of chang- ing their colour using radium. Later in his life he studied spiritualism. He was elected a Fellow of the Royal Society in 1863 and became President in 1913. He was knighted in 1897. He also received many other honours and awards.

\section{Crookes family genealogy}

Sir William Crookes never wrote an autobiography but in The Times in 1897 he contributed to a debate about longevity by referring to members of his own family in the $17^{\text {th }}$ and early $18^{\text {th }}$ centuries. His father used to listen to family stories told by his great-grandmother (1710-1814) when she was over 100 years old. She had in turn heard them from her grandfather ( 1639-1729) who lived through the plague year of 1665 . (The plague was brought by visitors

Cartmel

Grange over Sands

Cumbria LA11 6QG

United Kingdom 


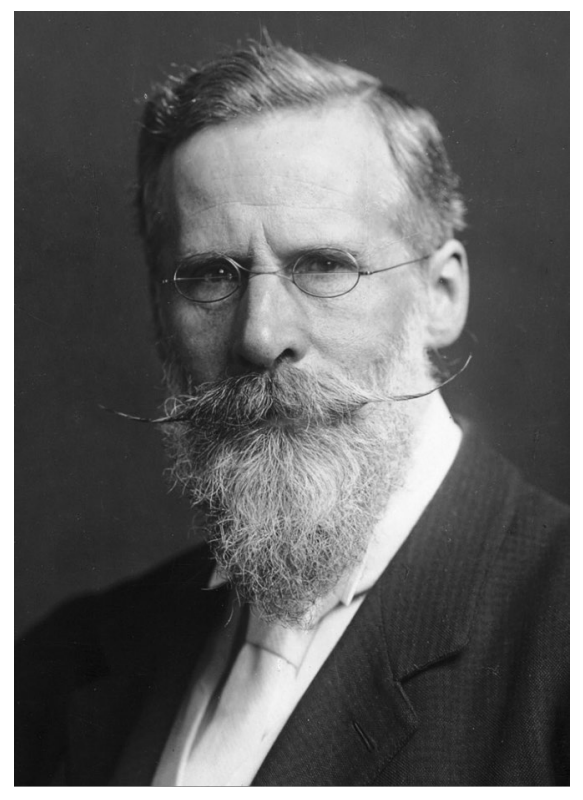

Figure 1. Sir William Crookes

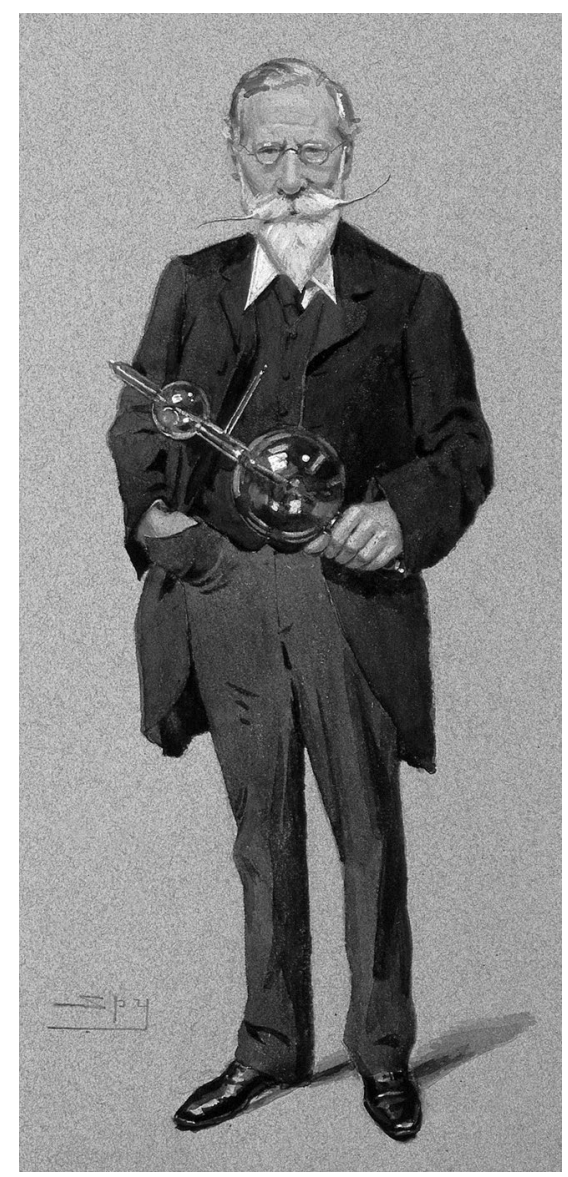

Figure 2. Cartoon by Spy

from London.) He was from Staveley in Derbyshire and was one of the few in the village who survived. He was employed bringing out the dead from house-to-house and taking them on horse-drawn sledges for burial in Marstin/Marston Moor. The future Sir William was born four generations later.

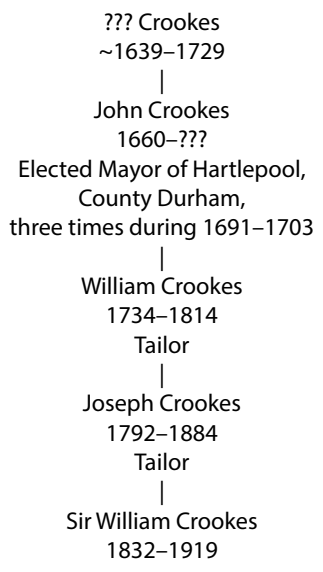

\section{Joseph Crookes (1792-1884): Sir William Crookes' father}

Joseph Crookes (1792-1884) was the eldest of four sons and became an apprentice tailor in Sheffield. However, for some reason he never completed his apprenticeship and in 1811 moved to London. To achieve this he walked all the way from Sheffield: which method of travel was not unusual at the start of the $19^{\text {th }}$ century for those who were not wealthy and hoping to make a fortune in London. Joseph next surfaces as an assistant to a tailor called Atkinson. In the 1820 s they moved to premises at 143 Regent Street: in Thomas Tallis' London Street Views of 1838 , the entry for 143 is 'Atkinson \& Crookes, Tailors \& Habit Makers'. By then Joseph had become a partner. Atkinson retired in the 1830 s and earlier in the 1810 s, Joseph had married his partner's daughter. It is thought that they had five children: three sons \& two daughters but only one daughter has been traced.

In the 1856 Post Office Directory the entry for 143 Regent Street is 'Crookes Joseph \& Alfred, tailors'. In the 1860 death certificate for Joseph Jr, who died in 1860, the elder Joseph Crookes (1792-1884) was described as a 'retired tailor'.

Joseph Snr's $1^{\text {st }}$ wife Jane died in childbirth in the late $1820 \mathrm{~s}$. His $2^{\text {nd }}$ wife was Mary Scott, the daughter of John Scott of Aynhoe, Northamptonshire. The marriage took place in Aynhoe in 1831 and the couple had 16 children but only 8 survived into adulthood. The future Sir William was the eldest child of this marriage.

In the 1843 Post Office Directory for London, Michael Coomes is a'Bookseller \& Stationer' at 141 Regent Street. He is also recorded as having his shop at No.141 in the 1856 Directory. Mary Scott's sister Martha who is known to have married a bookseller lived at No.141. It is therefore likely that Michael Coomes was her husband. Joseph Crookes Jr (1818-1860) and his brother Henry Crookes (1821-1841) were both booksellers and perhaps worked with their uncle at No. 141 [2-5]. 
The registration district for the births of Charles Edward and Francis in 1838 and 1839 was St. James Westminster, whereas that for Emily Martha, Alice Martha and John Philip Edwin in 1841, 1844 and 1846 was St. Pancras. These were all children of Joseph Crookes (1792-1884).

\section{George Crookes (1802-1877): Sir William Crookes' uncle}

George Crookes (1802-1877) was a brother of Joseph Crookes Snr, and was also a master tailor. His premises were in St. James Street, Piccadilly. His son was George William Crookes (1840-1873), also a master tailor, who predeceased his father. George William had one sister, Elizabeth (1837-1877) and one brother, Arthur (1843-1868). The registration district for the births of both George William and Elizabeth was St. George Hanover Square.

\section{Joseph Crookes Jr. (1818-1860): Sir William Crookes' half-brother}

Their eldest son of Joseph Crookes (1792-1889) was Joseph Jr (1818-1860). \{The Jr actually appears on his wedding certificate \& Will.\} He was living at 143 Regent Street when he married in 1842 Frances Blake of Sheffield. Her father Thomas Blake was a merchant. The registration district for this 1842 marriage was St. Pancras.

The cause of death of Joseph Jr., was certified as 'chronic softening of the brain of 2 years duration'. At the time of his death he was living at Clarendon Villas, Brook Green in the registration district of Hammersmith.

\section{Alfred Crookes (1823-1903): Sir William Crookes' half-brother}

In the 1881 census return Alfred is described as a Master Tailor employing 15 men and 5 women. His home address was 15 Holland Park Terrace. He married Elizabeth ... (1825-1905) in 1846 in the registration district of St. George, Hanover Square. They only had one child, Eleanor Jane (1848-???) who married in 1874.

\section{Francis Crookes (1839-1892): Sir William Crookes' brother}

Francis was born in Regent Street. In 1861 he was unmarried and living with his parents and his unmarried sister Jane (age 41) who was born in Hatton Garden, at Masbro House, Brook Green, Hammersmith. At this time his father, Joseph Snr, was described as'a proprietor of land and house'. In the 1871 census Francis was described as a master tailor employing 11 men and 2 women; and in 1881 as a military outfitter employing 15 work people.

Francis was married in 1867 at St. Michael, Highgate, to Anne Scott (1847-1926) who was born in Aynhoe, Northants. Her father was a farmer, John Scott. She must have been a relative of Joseph Snr's second wife Mary Scott
(1806-1884), also of Aynhoe. They had at least six children, all of whom were found in the 1891 census, residing in Richmond, with Francis described as 'living on own means'. The children were Philip Francis (1870-1899) a law student; Charles Reginald (1871-1927) a surveyor in 1891 but in 1911 unmarried \& a teacher of physical training; Percy Scott (1872-1896) a medical student; Mabel Annie (1878-1947); Emily Gladys (1883-1954) unmarried; and Elsie Marion (1886-1940) unmarried.

\section{John Philip Edwin Crookes (1846-1867): Sir William Crookes' brother}

Known as Philip he was involved in telegraph cable laying from an early age. In 1864 in India he was in charge of cable testing and in 1866 monitoring signals at Valentia after the successful laying of the Atlantic cable. In 1867 he was one of the engineers of the India-Rubber \& Gutta Percha Telegraph Company on the ill-fated Florida-Cuba expedition. In the 18 August 1867 issue of The Times the following report from Havana was given. 'The sanitary report of this island (i.e., Cuba) for the month of July states that there has been 1,219 cases of yellow fever, of which 226 resulted in death. There were also 134 deaths from smallpox.'Philip died from yellow fever on 22 September 1867. A book of Philip's letters from 1867 to his family was edited and typeset by his brother William Crookes (he mentions by name only his 'sister Jane') who published it in 1868. "In Memoriam. The Last Letters of John Philip Edwin Crookes. Ad Plures Abiit Sept. 22, 1867, Aetat 21. Sic Itur Ad Astra".

\section{Engineering \& science versus trade as an occupation}

In the $19^{\text {th }}$ century, trade as an occupation was looked down upon when compared to occupations in the law, medicine, army and the church. It is therefore interesting to find, using the evidence of occupations, that the Crookes family would have become upper middle class in the generation after Sir William.

Of those 7 with a known occupation and of the same generation as Sir William Crookes, only two (William \& John Philip Edwin) were in Engineering \& Science. Of the remaining 5 there were 2 tailors, 2 booksellers and a wine merchant. John Philip Edwin was reported as being the favourite brother of Sir William: perhaps because of shared scientific/engineering abilities or perhaps because William who was 14 years older than Philip, helped to look after him when he was a child. There is no record I can find of William referring to any of his other siblings (or indeed of his own children). He must have been singly-minded on science with no time left for family matters, except for devotion to his wife. Apparently he was going to write an autobiography, but his wife's death caused him such pain that he never accomplished this task. 
In the next generation, of those surviving to adulthood, (sons of William and Francis) there are 8 with a known occupation. These were an analytical chemist, electrical engineer, civil engineer, 2 solicitors, accountant, doctor and surveyor, and not a single tailor. This indicates the upward mobility of the Crookes family.

The addresses of the tailors were in the most upmarket area of central London and they were probably wealthy and therefore able to fund the education of their children. Several sources state that Sir William received a large legacy from his father, which enabled him to set up his own laboratory around 1861, the time when he discovered thallium. However, his father did not die until 1884 so there is an error somewhere. Maybe his father just gifted money to William, since he had successfully invested in land and property. Whatever the truth of the matter, after Sir William obtained his own laboratory at his home, he professionally went from strength to strength.

\section{Family Tree: Joseph Crookes' $1^{\text {st }}$ marriage 1817}

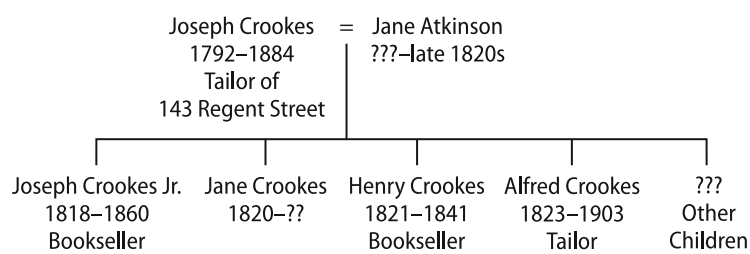

Family Tree: Joseph Crookes' $2^{\text {nd }}$ marriage 1831
Sir William Crookes married on 10 April 1856 by license in St. Pancras church, London, 18-year old Ellen Augusta Humphrey (1838-1916) who was born in Darlington, Durham, the daughter of William Humphrey who was deceased. William was then aged 24 . On the marriage certificate it stated that the William's father's rank or profession was 'Gentleman'. William's rank or profession was 'Professor of Chemistry' and his residence at the time of his marriage was 'St. Paul, Knightsbridge'. William \& Ellen had eight children, some of whom predeceased their parents. Their two sons, Bernard \& Lewis, were granted probate when Sir William died, leaving in excess of $£ 30,000$. William and Ellen had lived for many years at 7 Kensington Park Gardens [2-5].

Alice Mary (1857-???) was at the time of the 1881 census living in Kensington with her parents. In 1897 she married a solicitor. Henry (1859-1915) trained as a mining engineer at the Royal School of Mines (now included in Imperial College, London). He died in Kensington. John William (1863-???) emigrated to Canada. Bernard Humphrey (1865-1930) was living in Jesmond, Northumberland at the time of the 1911 census but lived in Newcastle at the time of his death. Walter Scott (1867-1935) age 43 and single, was living with his parents at the time of the 1911 census. Nellie (1870-1870) survived only a few weeks. Florence Ellen Jane (1871-1884) died of typhoid fever. Lewis Philip (1874-1954) lived in Westmorland at the time of his death. The schools attended by the brothers appear to have been University College School from the age of 11 years for 2-3 years and then Felstead Grammar School, Essex [2-5].

\section{Marriage \& children: Sir William Crookes}

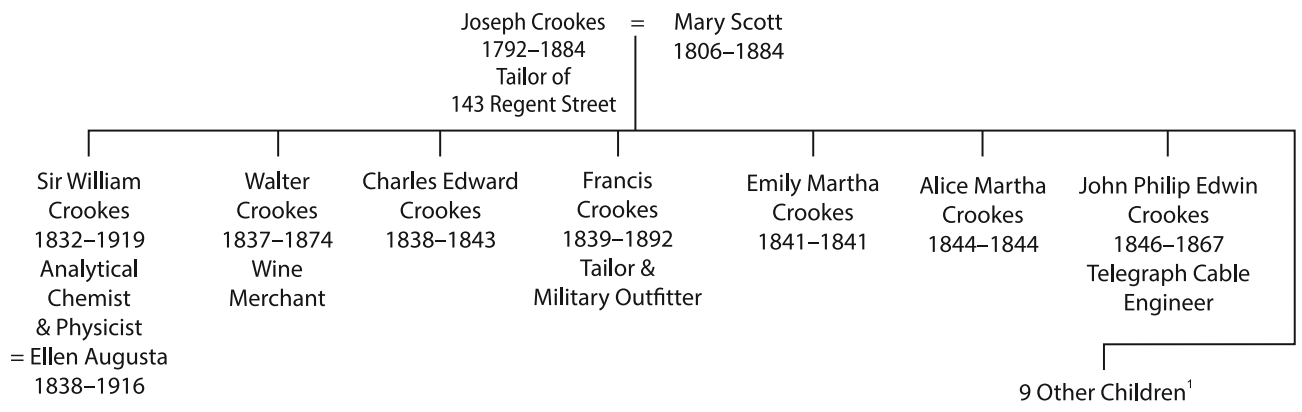

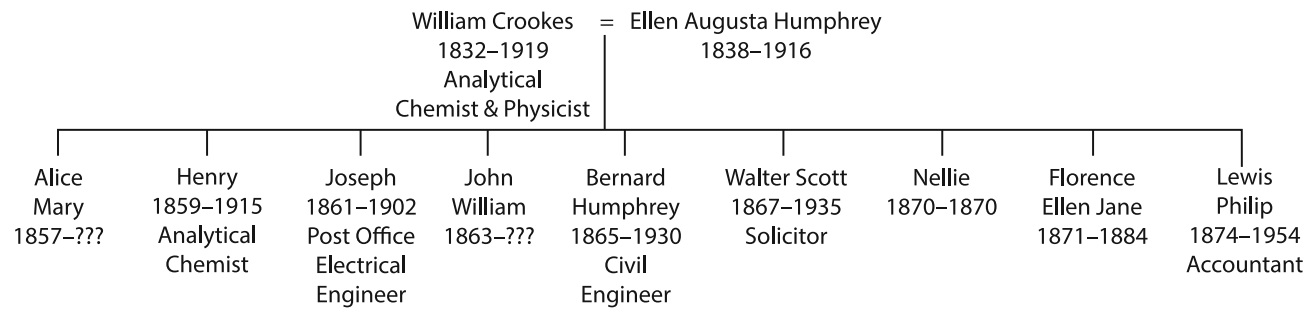

\footnotetext{
1 The earliest birth, death \& marriage certificates available from the General Register Office are from September 1837 . The earliest census return is 1841 (thereafter every 10 years). Census returns are released to the general public after 100 years and thus the latest available census return is for 1911 . These limitations sometimes make it difficult to identify those born before 1837 when it is likely that there were some Crookes births.
} 


\section{Early years}

William Crookes received relatively little formal education during his very early years. However, at the age of 16 he entered the Royal College of Chemistry with the aim of studying organic chemistry. Whilst at the College he became the assistant of August Wilhelm von Hofmann (1818-1892) and this enabled him to attend meetings at the Royal Institution; where he met Michael Faraday (1791-1867) who convinced him to change his area of study from chemistry to physics, and particularly optics. After graduation from the College in 1854 he took up the post of Superintendent of the Meteorological Department at the Radcliffe Observatory, Oxford. However, he remained only for a year and in 1855 became a Lecturer in Chemistry at Chester Training College. Again, this was only for one year. He appears to have received a substantial inheritance (or perhaps funding from his father who lived until 1889) which enabled him to set up how own laboratory and concentrate on physics. In 1859 he founded the journal Chemical News which made him widely known, and remained its Editor and owner all his life.

\section{Thallium}

Thallium (atomic number of 81) was discovered in 1861 independently by William Crookes and the French chemist Claude-Auguste Lamy (1820-1878). The name thallium was proposed by Crookes after the Greek thalllos meaning a green shoot or twig. Crookes made flame spectroscopic studies on tellurium (which produces yellow spectral lines) extracted from selenium compounds deposited in a lead chamber of a sulphuric acid production plant. He found a previously unknown bright green spectral line: thallium had been discovered. The next year, 1862, he isolated samples of thallium salts and grains of powdered metallic thallium in 1862 and exhibited them at the London International Exhibition in May of that year. Lamy also exhibited this Exhibition, with more material than Crookes: an ingot of the purse metal and was awarded a medal at the Exhibition for 'the discovery of a new abundant source of thallium'. Crookes made a heavy protest and eventually also received a medal, for 'the discovery of the new element'. The controversy between the two chemists continued throughout 1862 and 1863, and only effectively ended when Crookes was elected in June 1863 a Fellow of the Royal Society.

The major use of thallium, which is extremely toxic, was for poisoning rats and ants but after several accidents it was banned in 1972 from household use in the USA, by a Presidential Executive Order. Many other countries followed this course of action.

Thallium has also been used medically, such as in the treatment of ringworm in the 1930s (thallium acetate) and in cardiac scanning using a gamma camera in the $1980 \mathrm{~s}$ (100 MBq thallium-201 chloride). From 1929 to the mid- 1950s/early 1960 s thallium was used as a diagnostic contrast agent in the form of thorium dioxide in colloidal suspension (commercially named Thorotrast). This was a disaster of epic proportions since it was found to have carcinogenic properties. Many countries were involved, including Denmark (140 epileptics were given Thorotrast during cerebral angiography), Germany, Japan and Portugal. In Germany most of the patients were injected intravascularly during 1937-1947. In a German study of 2326 Thorotrast cases and 1890 controls, diseases with high excess mortality were liver cancer, liver cirrhosis, myeloid leukaemia and bone marrow failure [6-18].

Ending on a rather different note! Thallium poisoning was historically popular as a murder weapon (Agatha Christie used it as a method of murder in her novel The Pale Horse.) and for this reason (together with arsenic) it has been known as 'the poisoner's poison' and 'inheritance powder' [17].

\section{Electrical discharges through gases: Introduction}

Scientists before and after Sir William Crookes undertook experimental studies on electrical discharges through gases (the general term cathode ray research was often used by experimenters prior to the use of the name electron), particularly in the latter third of the $19^{\text {th }}$ century. Even after the discovery of X-rays the topic retained its interest. For example, in 1896 at the Cavendish Laboratory in Cambridge, Sir Joseph J Thomson (1856-1940) (who was to discover the electron in 1897) and Ernest Rutherford (1871-1937) published on the topic $[19,20]$. Thomson had been studying electrical discharges through gases under varying conditions of pressure. However, success in these studies depended on manufacturing quality of discharge tubes and the ability to obtain good evacuation of the discharge tube.

Figure 3, after Mayneord [21], is a line drawing of a 'simple discharge tube'. The glass tube has sealed into it two metal electrodes $A$ and $B$ and connect the side tube to an air pump. At normal atmospheric pressure, no current will pass through the tube. However, when the air is gradually

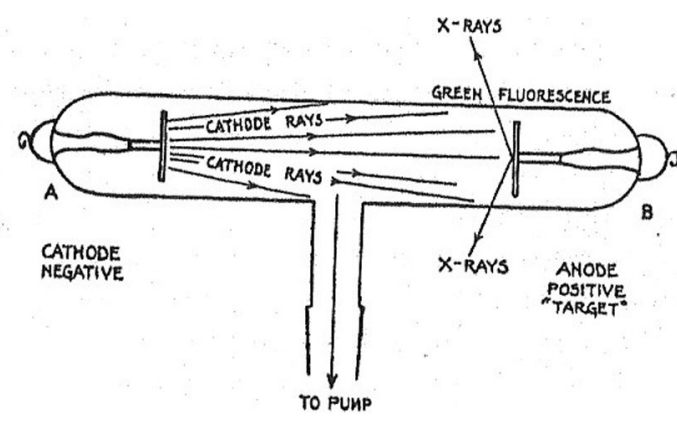

Figure 3. Schematic of an electrical discharge tube 
removed and the voltage difference applied to $A B$ is sufficiently large (e.g., 10,000 volts), after a complex series of changes of appearance of the discharge which passes at low pressures, it is found eventually that a new type of radiation is proceeding in straight lines from the negative electrode (cathode) and striking the walls of the vessel. This radiation reveals itself by a pale apple-green fluorescence of the walls of the walls of the tube (if the tube is made of soda glass), and by the luminescent glass becoming hot. Moreover, the radiation may be bent out of its straight path by a magnet held near the tube. The movement of the fluorescence when the magnet is presented, together with many other experiments, demonstrates conclusively that the radiation from the cathode must consist of negatively charged particles (the electrons) moving with high velocities down the tube away from the cathode.

\section{Discharge tubes \& air pumps}

The start of this field of study might be said to have begun with the invention in 1654 of the first mechanical air pump by Otto van Guericke (1682-1686), the burgomaster of Magdeburg. His aim was to create a vacuum in which to study celestial conditions. He speculated that the earth was a great electrical machine 'rotated by the hand of the Almighty and excited by the friction of the solar rays', [22]. In 1660 the Guericke air pump was improved by Robert Hooke (1635-1703) and Robert Boyle (1627-1691). These air pumps incorporated a piston type design.

Michael Faraday (1791-1867) studied in the early 1830s, electric discharges from evacuated tubes that contained small amounts of rare earth. However, he experienced the limiting factors of the quality of the glass tubes and the inefficient methods of producing high vacuums. His name became associated with the dark space surrounding the negative electrode, the size of which depended on many factors such as the vacuum and the potential difference at the electrodes. At the time three states of matter were recognised: solid, liquid and gaseous. Faraday suggested that luminosity of highly rarefied gaseous material in a vacuum tube when excited by electricity was a property of matter in a fourth state. He termed this radiant matter.

The technical problems experienced by Faraday were in part overcome by the German glassblower Johann Heinrich Geissler (1815-1879) who introduced in 1855 a practical mercury air pump which could lower the air pressure to 2 torr. (The torr is a unit of pressure now defined as exactly $1 / 760$ of a standard atmosphere. It is 133.3 pascals) Geissler had in 1854 opened a shop in Bonn to make scientific apparatus. He produced glass discharge tubes of many complex shapes and of different sizes. Using his new pump enough air could be extracted from his tubes to produce a relatively high vacuum, improving on existing discharge tubes. He also used platinum wire terminals, as the metal's expansion when heated matched that of glass. He produced luminous colour effects by applying high voltage currents from a Ruhmkorff coil and introduced small quantities of various gases into his tubes.

Two quotations from the end of the $19^{\text {th }}$ century indicate the influence Geissler had on scientists, [23,24].'The beautiful glow of the Geissler tubes lent a fresh attraction to the study (of electric discharges).' 'Geissler tubes elicit glows of many colours, vieing in beauty with the fleeting glints of the aurora polaris. By 1865 the design of the mercury air pump was further improved by Hermann Sprengel (1834-1906) so that enough air could be extracted from glass tubes to produce a much better vacuum than did Geissler. Sprengel pumps were used by Crookes.

The German physicist Julius Plücker (1801-1868) also investigated the discharges in Geissler tubes and was the first to observe glass fluorescence (green in glass of British manufacture and blue in German glass) in the tubes opposite one of the electrodes. With his student Johann Wilhelm Hittorf (1824-1914) he discovered that the diffuse light (Faraday's radiant matter) emanating from the cathode could be concentrated by the use of a magnet.

\section{Crookes tubes}

William Crookes was fascinating by Faraday's hypothesis and built a wide variety of vacuum tubes containing various terminals and internal devices, in order to study the properties of this radiant matter. His high vacuum tubes together with those of other investigators became generically known as Crookes tubes. (It is not recorded who designed the famous pear-shaped discharge tube, of the type which Röntgen used to discover X-rays.) Of the many experiments made by Crookes, perhaps the most famous also involved a pear-shaped tube, one in which was inserted a Maltese cross made of mica, Figure 4 . Crookes showed that when

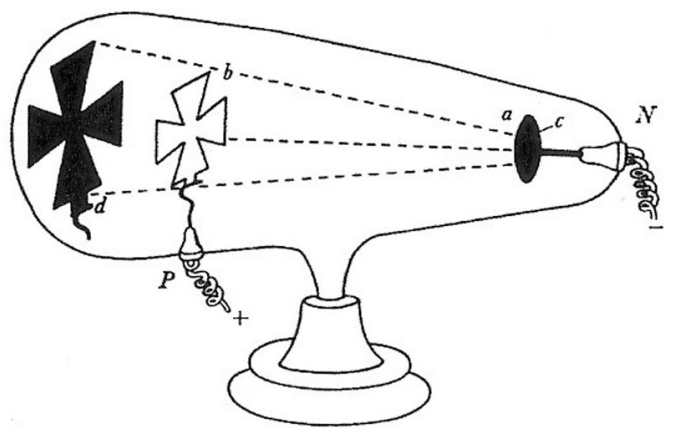

Figure 4. Tube used to demonstrate that cathode rays travel in straight lines

the tube was energised a clear black shadow was seen in the otherwise fluorescent glow, indicating that the cathode rays travel in straight lines. 
Another experiment involved a paddle whee/ with vanes of transparent mica inside the discharge tube. When a current was applied to the electrodes fastened to the outside of the tube, the wheel revolved: when the current was reversed the wheel rotated in the reverse direction. The speed of the revolution was in proportion to the intensity of the incident cathode rays.

A device invented in 1873, known as a Crookes' radiometer (a drawing of a radiometer appears on the coat of arms of William Crookes) or a light mill, consisted of four small vanes mounted on a spindle. The two sides of each vane were painted in different colours, one black and the other white. The entire assembly was sealed in a vacuum bulb [25]. The vanes rotate when exposed to sunlight, artificial light or infrared radiation, (i.e., electromagnetic radiation) with faster rotation for more intense light. The reason for the rotation was a cause of much scientific debate for the next decade. Crookes incorrectly suggested that the force was due to the pressure of light. The correct explanation [26] is that on average the gas molecules move from the cold side towards the hot side whenever the pressure ratio is less than the square root of the (absolute) temperature ratio. The pressure difference causes the vane to move, cold (white) side forwards due to the tangential force of the movement of the rarefied gas moving from the colder edge to the hotter edge.

Crookes devised a tube, Figure 5, to demonstrate that cathode rays yield heat. The concave cathode $A$ focuses the rays on a piece of metal $B$, which leads to fluorescence. Even

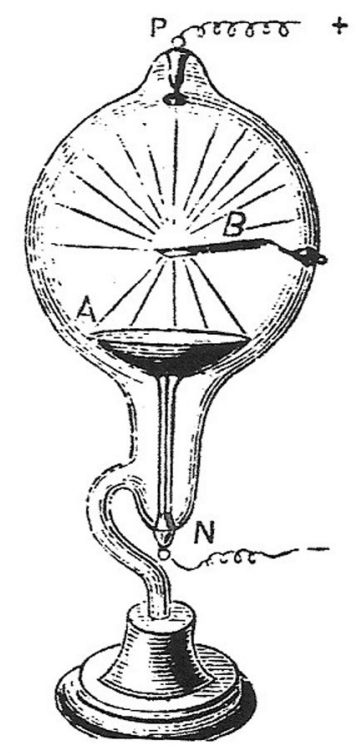

Figure 5. Tube to demonstrate that cathode rays yield heat

refractory metals such as platinum were melted and fused $[22,27]$. However, the most important aspect of this particu- lar Crookes' tube which he made in 1879 was that with its concave cathode it was the prototype of the focus tube [28].

\section{X-rays missed!}

Figure 6 shows William Crookes in 1879 demonstrating the deflection of cathode rays using a magnet. On $20^{\text {th }}$ January 1896, only, after Röntgen's discovery had been announced, Crookes used the same 1879 electrical discharge

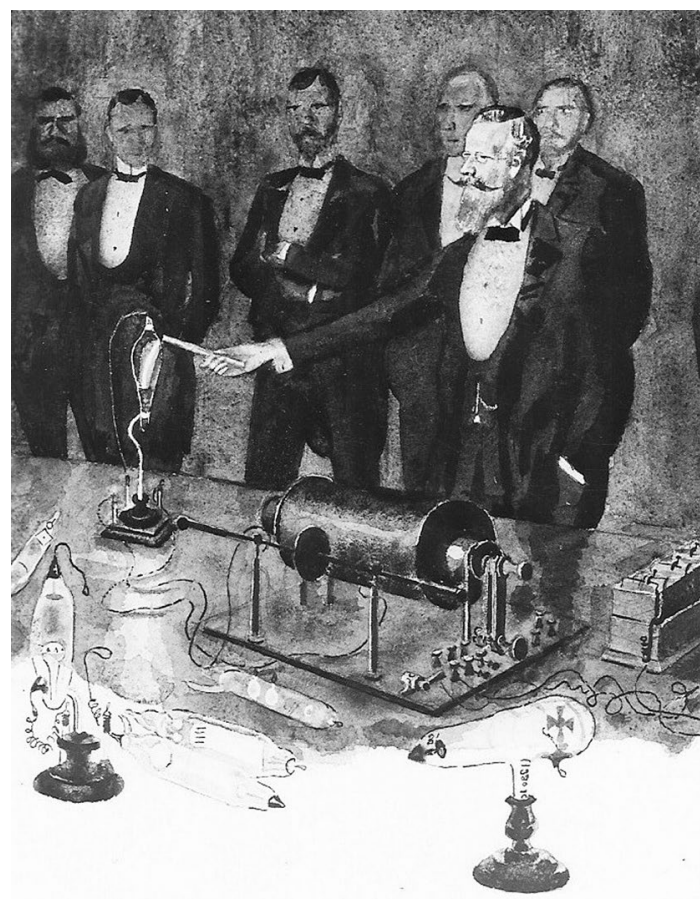

Figure 6. William Crooks in 1879

tube to intentionally demonstrate the production of X-rays. It is well documented that Crookes had previously made the observation that photographic plates stored near his tubes became fogged, and that on one occasion he returned the plates to the manufacturer, Ilford Ltd., as unsatisfactory.

\section{Coat of arms}

Figure 7 shows Sir William Crookes' coat of arms. 'Ubi Crux Ibi Lux' translated as 'Where the cross is there is light'. Crux' is a play on words since it is thought (but not proven)

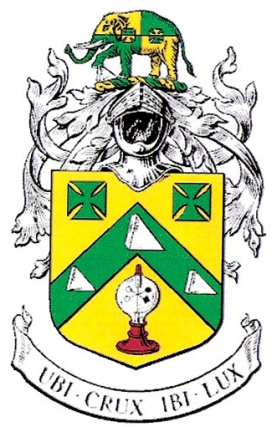

Figure 7. William Crookes' coat of arms 
that the earliest known members of the Crookes family were crusaders from the village of Crux (now Crooks) a suburb of Sheffield. The elephant in included because of the pet name of William Crooks' wife: 'Ellie' for Ellen. The armorial symbols are three prisms, four Maltese crosses and a radiometer [29].

\section{Antoine-Henri Becquerel and William Crookes}

William Crookes was one of the eyewitnesses on 1 March 1896, another was Jean Becquerel (1878-1953), who witnessed Antoine-Henri Becquerel's (1852-1908) discovery of the phenomenon of radioactivity [30]. Becquerel's first report [31] to the Académie des Sciences, Paris, on using the bisulphate of uranium and potassium, was on 24 February 1896 and gave the impression that it appeared that X-rays were emitted from the uranium salt while fluorescing [32]. His concluding remarks were 'From these experiments it may be concluded that the phosphorescent substance emits radiations which penetrates paper that is opaque to light and reduces silver salts in a photographic plate' [31].

To confirm these findings Becquerel decided to repeat the experiment on 27 and 28 February 1896. However, the sun was mainly overcast on those days and consequently he stored the arrangement of plates and uranium salt in a drawer. It is not known why Becquerel decided to develop the unexposed plate on 1 March. He reported to the Académie [32] that he had shown that the film blacking was not connected with sunlight nor caused by luminous radiation emitted by phosphorescence [33].

The eyewitnesses in Paris on 1 March 1896 included William Crookes. Becquerel was later to give Crookes an image of one of his early experiments, Figure 8, which he described in his 1903 Nobel Lecture [34]. The handwriting and the sketch of the bell-jar covering a sample of calcium sulphide were added later for the benefit of Crookes. The address of Becquerel's laboratory at the Muséum National

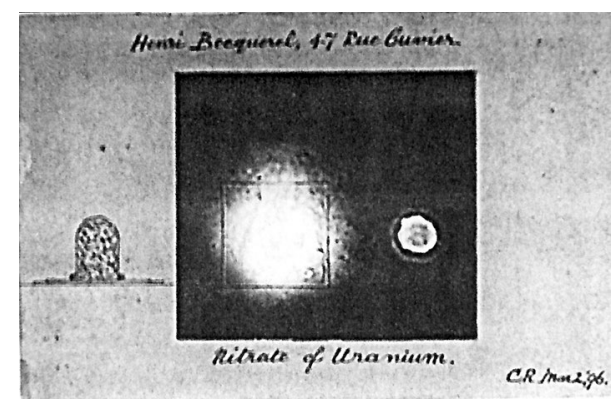

Figure 8. Image an experiment which was given by Becquerel to Crookes

$\mathrm{d}^{\prime} \mathrm{Histoire}$ Naturelle is at the top of the figure. The other wording is 'Nitrate of Uranium' and 'CR March 2 '96.' The samples of phosphorescent calcium sulphide resting on small plates of glass were covered with a small bell-jar and were laid on a photographic plate by a sheet of aluminium $2 \mathrm{~mm}$ thick. The print was developed after 48 hours and revealed silhouettes of the glass plates, reproduced with the details which would have been produced by refraction and total reflection of the light rays, [34].

\section{Spinthariscope}

Crookes proposed to call this instrument a spinthariscope from the Greek word spintharis - a scintillation. Descriptions of this instrument appeared in many of the early textbooks on radium and that by Levy \& Willis from 1903 is a typical example [35]. They start by stating that the physical effects (e.g., luminous effects) are all due either to the emanation or rays, rather than to the radium itself. Alpha rays, moving with very great velocity, cause certain substances to flash by their actual impact. The effect is shown by a spinthariscope, (Fig. 9) of which there are many forms which though differing in detail are essentially similar.'Typically it consists of a short brass tube, carrying at one end a screen coated with hexagonal zinc sulphide. At a distance above the screen of about $1 / 8$ inches is a watch-hand, carrying on the side facing the screen a small fragment of radium nitrate. A short focus powerful lens magnifying about 20 diameters, through which the screen can be viewed. If the screen were viewed without the lens it would present the appearance of a very faint glow. In a darkened room, using the lens, the appearance is that of a number of shooting stars. The screen appears as a black background covered with numerous scintillations, which are continually flashing forth, only to die away again.'

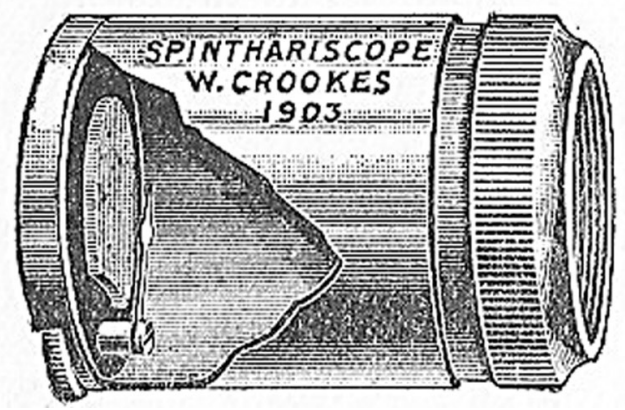

Figure 9. Example of a spinthariscope

The spinthariscope has been used in many variations but perhaps none so unusual as the toy called the Lone Ranger Atom Bomb Ring (an example is in the Oak Ridge Associated Universities Health Physics Museum). This was distributed in 1947 by Kix Cereals of New York City. The ring cost 15 US cents plus a Cereals box top! 'You'll see brilliant flashes of light in the inky darkness inside the atom chamber. These frenzied brilliant flashes are caused by the released energy 
of atoms. We guarantee you can wear the Kix Atomic Bomb Ring with complete safety. The atomic materials inside the ring are harmless.' The red base of the ring was supposed to serve as a secret message compartment. When it was removed, after a suitable time for dark adaption, you could look though a small plastic lens at scintillations caused by polonium alpha particles striking a zinc sulphide screen [36].

\section{Diamonds and radium}

After the discovery of radium in 1898 it was soon found that diamonds exposed in the dark to radium rays fluoresce and scintillate in the most brilliant fashion [37] and it was noted that blue-white diamonds exhibited the greatest fluorescence [38].

Crookes experimented with two South African diamonds from Kimberley, one irradiated by a radium bromide source and one not irradiated $[39,40]$. 'Two Bingara diamonds $A$ and $B$, weighing respectively 0.960 and 1.020 grains, were selected as near the eye could judge of the same size and colour: very pale yellow known as 'off-colour'. Diamond A was put in a drawer far removed from radium or any radioactive body. Diamond B was kept close to a quartz tube containing about $15 \mathrm{mg}$ pure radium bromide and sealed in vacuo. It phosphoresced brightly and continued to glow the whole time of the experiment.

After a fortnight the two diamonds were placed side by side and compared. There was no appreciable difference in colour between them. Diamond B was then placed close to the quartz tube of radium, and they were kept in contact for six weeks. At the end of that time examination again showed scarcely any difference.

Diamond $B$ was now put inside a tube with radium bromide, the salt touching it on all sides. The experiment continued for 78 days when the two diamonds were again examined. There was now a decided difference in colour between them; diamond A was of its original pale yellow; but diamond $B$ was of a darker appearance and of a bluishgreen tint with no yellow colour apparent. The green colour of diamond B has persisted. It was donated by Crookes in 1916 to the Natural History Museum, London. Crookes was also to write in 1909 a book on Diamonds [41].

\section{Spiritualism}

The $19^{\text {th }}$ century in Victorian England, following its popularity in 1850s USA, saw the rise of spiritualism with its supposed physical manifestations and supernatural phenomena. If the dead could materialise during séances, would this not prove that afterlife existed? Some of spiritualism's supporters included leading figures such as Sir Arthur Conan Doyle (1859-1930) who wrote the Sherlock Holmes stories and Sir William Crookes. However, not all who attended séances were believers and some were just interested persons hoping to see mediums proven to be fakes.
William Crookes became interested in spiritualism in the late 1860s, maybe because he was interested in contacting his dead brother John Philip Edmund Crookes (1846-1867) who had died of yellow fever in Cuba. It is known that Crookes in 1867 had been persuaded by the electro-physicist Cromwell Fleetwood Varley (1828-1883) who was a pioneer of intercontinental telegraphy, as well as a clairvoyant, to try to make contact with his dead brother [42-45].

For four years, 1871-1874, William Crookes was very involved, publically, with spiritualism, when studying the mediums, Florence Cook (1856-1904) and Daniel Dunglas Home (1883-1886). Crookes allegedly witnessed movement of bodies at a distance, rappings, changes in weights of bodies, levitation of individuals and automatic writing. He believed, after his investigations that mediums could produce genuine paranormal phenomena.

In spite of his scientific achievements, not least the discovery of thallium, Crookes was widely criticised. One explanation put forward was that his eyesight was extremely poor. Indeed, Sir William Ramsay (1852-1916) the Nobel Prize winner in Chemistry in 1904, was quoted as saying 'Crookes is so short-sighted that, despite his unquestioned honesty, he cannot be trusted in what he tells you he has seen [5].

At a series of experiments in Crookes'laboratory in February 1875, the medium Anna Eva Fay (1851-1927) managed to fool Crookes into believing that she had psychic powers. However, Fay later confessed that she was a fraud [46]. The famous magician Harry Houdini (1874-1926) suggested that Crookes had been deceived with these studies [47]. The physicist Victor Stenger (1935-2014) considered that Crookes' experiments were poorly controlled and 'his desire to believe blinded him to the chicanery of his psychic subjects [48].

In 1906 William Hope (1863-1933) tricked Crookes with a fake spirit photograph of his wife. Sir Oliver Lodge (1851-1940), the Professor of Physics at Liverpool University and an X-ray physicist of renown at the end of the $19^{\text {th }}$ century and start of the $20^{\text {th }}$ stated that there had been obvious signs of double exposure. The picture of Lady Crookes had been copied from a wedding anniversary photograph [5].

Florence Cook, a materialisation medium endorsed by Crookes, was elsewhere repeatedly exposed as a fraud. She had been séance trained by the medium Frank Herne whose first séances were given in 1869 but whose materialisations were grabbed on more than one occasion and found to be the medium himself! The scientific establishment scented scandal since Florence was a pretty 18-year old girl and Crookes was then aged 41 and they spent much time alone together at Crookes home, locked into a dark room whilst apparitions were shown. Nobody but Crookes was ever reported as seeing these apparitions. Crookes took 44 photographs of the apparition Katie King (she claimed to be a girl of 12 when she stood in the crowed watching King Charles I 
being beheaded in 1649; she also claimed to have lived in Jamaica in the time of King Charles II \& gave vivid recollections of the Spanish Main to one of Crookes'daughters) in some of which he or Florence appear alongside Katie. Sceptics at the time considered that Crookes was being completely hoodwinked or that he had agreed to perpetrate the fraud with Florence. Florence had secretly married a Captain Corner who resented the time Florence spent with Katie King and gave Crookes a beating. Eventually, by 1880 , Florence was exposed as a fraud by Sir George Sitwell (1860-1943). The outrage about Crookes during the early 1870 s was so great that there was even talk of depriving Crookes of his Fellowship of the Royal Society. This must have worried Crookes as he ceased psychic experimentation in 1874 and did not discuss his views on spiritualism until 1898 in Bristol, when he was President of the British Association; and when he obviously felt more secure than some 25 years previously. There is no doubt, however, that he retained until his death, his belief in spiritualism $[49,50]$.

\section{Richard F. Mould, MSc, PhD}

4, Town End Meadow

Cartmel Grange-over-Sands

Cumbria LA116QG

United Kingdom

e-mail:manorroadsouthport@yahoo.co.uk

\section{References}

1. Crookes W. Select Methods of Chemical Analysis. London: Longman Green, 1871.

2. www.ancestry.com genealogical searches, accessed February 2016.

3. www.freebmd.org.uk genealogical searches, including census returns 1841-1911, accessed February 2016.

4. General Register Office searches for births, deaths \& marriages, accessed February 2016.

5. Brock WH. A Tailor's Son. In: William Crookes (1832-1919) and the Commercialization of Science. Aldershot: Ashgate Publishing; 2008

6. Crookes W. On the existence of a new element, probably of the sulphur group. Chemical News 3: 193-194; 30 March 1861. Reprinted in: Phil Mag 21: 301-305; April 1861.

7. Crookes W. Further remarks on the supposed new metalloid. Chemical News 3: 303; 18 May 1861.

8. Crookes W. Preliminary researches on thallium. Proc Royal Society 12: 150-159; 19 June 1862.

9. Lamy A. De l'existencè d'un nouveau metal, le thallium. Comptes Rendus 54: 1255-1262, 16 May 1862.

10. Crookes W. On thallium. Phil Trans Royal Society 153: 173-192; 1863.

11. Crookes W. On thallium. J Chem Soc London 17: 112-152; 1864.

12. Percival GH. The treatment of ringworm of the scalp with thallium acetate. Br J Dermatology 42: 59-69; 1930.

13. De Kosky RK. Spectroscopy and the elements in the late $19^{\text {th }}$ century: the work of Sir William Crookes. Br J History of Science 6: 400-423; 1973.

14. Lebowitz E, Greene MW, Fairchild R, Bradley-Moore PR et al. Thallium-201 for medical use. J Nuclear Medicine 16: 151-155, 1975.

15. James FAJL. 'Of medals and muddles' the context of the discovery of thallium. Notes \& Records of the Royal Society 39: 65-90; 1984.
16. Taylor DM, Mays CW, Gerber GB, Thomas RG, eds. Risks from Radium and Thorotrast. Report 21. London: Br Institute of Radiology, 1989.

17. Emsley J. Thallium. The Elements of Murder: a History of Poison. Oxford: Oxford University Press, 2006.

18. Peter A, Viraraghavan T. Thallium: a review of public health and environmental concerns. Environment International 2005; 31: 493-501.

19. Thomson JJ, Rutherford E. On the passage of electricity through gases exposed to Röntgen rays. Phil Mag 1896; 42: 392-407.

20. Thomson JJ. Electricity and Matter. New Haven: Yale University Press; 1904.

21. MayneordWV.The Physics of X-Ray Therapy. London:J\&A Churchill; 1929.

22. Eisenberg RL. Predecessors of Röntgen. In: Eisenberg RL. Radiology an Illustrated History. St. Louis: Mosby Year Book Inc; 1992, pp 3-21.

23. Munro J. The Story of Electricity. London: George Newnes; 1897.

24. Phillips CES. Bibliography of X-Ray Literature and Research 1896-1897. London: The Electrician Printing \& Publishing Company; 1897.

25. Crookes W. On attraction and repulsion resulting from radiation. Phil Trans Royal Society 1874; 164: 501-527.

26. Gibbs P. How does a light millwork? http://math.ucr.edu/home/baez/ physics/index.html 1996.

27. Lerch IA. The early history of radiological physics: a fourth state of matter. Med Phys 6: 255-266, 1979.

28. Isenthal AW, Ward HN. Practical Radiography. $2^{\text {nd }}$ edn. London: The Photogram Ltd., 1898.

29. Numericana. Escutcheons of Science. http://www.numericana.com/ arms/crookes.htm

30. Mould RF. Antoine-Henri Becquerel 1852-1908. Nowotwory J Oncol 2008; 58; 258e-270e, [in English]; 554-564 [in Polish].

31. Becquerel H. Sur les radiations émises par phosphorescence. Comptes rendus de l'Académie des sciences. 24 February 1896; 122: 420-421.

32. Dahl PF. Flash of the Electrode: a History of JJ Thomson's Electron. Bristol: Institute of Physics Publishing, 1997.

33. Becquerel $\mathrm{H}$. Sur les radiations invisibles émises par les corps phosphorescence. Comptes rendus de l'Académie des sciences 1896; 122:501-503.

34. Nobel e-Museum.http://www.nobel.se/physics/laureates/1903/index.html

35. Levy LA, Willis HG. Radium \& Other Radioactive Elements. A Popular Account Treated Experimentally. London: Percival Marshall \& Co., 1904.

36. Frame P. Oak Ridge Associated Universities Health Physics Historical Instrumentation Collection. 2005. http://www,orau.org/pp/museumdirectory.htm.

37. Cleaves MA. Light Energy: its Physics, Physiological Action and Therapeutic Applications. New York: Rebman, 1904.

38. Kunz GF, Baskerville $C$. The action of radium, actinium, Roentgen rays and ultra-violet light on minerals and gems. Science 1903; 18: 769-783.

39. Crookes W. The emanation of radium. Proc Royal Society 1903; 71: 405-408.

40. Crookes W. On the action of radium emanations on diamond. Proc Royal Society $1904 ; 74:$ 47-49.

41. Crookes W. Diamonds. London: Harper Bros., 1909.

42. https://en.wikipedia.org/wiki/William_Crookes.

43. Lyons SL. Species, Serpents, Spirits, and Skulls: Science at the Margins in the Victorian Age. New York: State University of New York, 2010.

44. Jolly M. Faces of the Living Dead: the Belief in Spirit Photography. Melbourne: Miegunyah Press/Melbourne University Publishing, 2006.

45. Crookes W. Researches in the Phenomena of Spiritualism. Cambridge Library Collection - Spiritualism and Esoteric Knowledge, 2012. [Originally published in 1874: collection of reports by Sir William Crookes].

46. Polidoro M. Anna Eva Fay: the mentalist who baffled Sir William Crookes. Skeptical Inquirer 2000; 24: 36-38.

47. Houdini H. AMagician Among Spirits. Cambridge: Cambridge University Press, 2011.

48. Stenger VJ. Physics and Psychics: the Search for a World Beyond the Senses. Amherst: Prometheus Books, 1990.

49. Keene ML. The Psychic Mafia. Amherst: Prometheus Books, 1997.

50. Lehman A. Victorian Women and the Theatre of Trance: Mediums, Spiritualists. Jefferson: McFarland Publishing, 2009. 